Ye. K. Babets ${ }^{1}$, Cand. Sc. (Tech.), Prof., orcid.org/0000-0002-5613-9779,

O.P. Bielov ${ }^{2}$, orcid.org/0000-0002-3283-9527, O. O. Shustov ${ }^{2}$, Cand. Sc. (Tech.), orcid.org/0000-0002-2738-9891,

T.V. Barna ${ }^{2}$, Cand. Sc. (Geol.-Miner.), orcid.org/0000-0002-3152-8778,

A. A. Adamchuk ${ }^{2}$,

orcid.org/0000-0002-8143-3697

\title{
THE DEVELOPMENT OF TECHNOLOGICAL SOLUTIONS ON MINING AND PROCESSING BROWN COAL TO IMPROVE ITS QUALITY
}

Purpose. Reasoning and development of technological solutions on the open deposit development and processing of brown coal to improve its quality features and usage at energy production enterprises.

Methodology. To solve the set problems, the following research methods were used: analytical evaluation of the resources of brown coal deposits; geological and engineering and hydro-technical analysis; system and feasibility studies on mining operation indicators and parameters of coal processing; laboratory tests, field experiment.

Findings. A reasonable technological scheme for developing an open brown coal deposit of Ukraine was proposed. Justified planned parameters of mining brown coal with extension of productivity of the brown coal quarry of Novo-Dmytrovskyi deposit (provided this project implementation) are up to 9 million tons a year, and up to 20 million tons a year provided the involvement of coal clays as a mineral, respectively. Technological solutions for thermal vacuum and separation modification of brown coal have been developed. The qualitative characteristics of the obtained concentrate for the further application at energy production enterprises have been established: the mixture ash content for the fuel working state $\left(A^{r}\right)$ after heat treatment made $50.2 \%$, and after separation - $17.72 \%$; lower combustion heat $\left(Q_{t}^{r}\right)$ increased from 3316.1 to $5817.7 \mathrm{kcal} / \mathrm{kg}$; mass portion of sulfur $\left(S_{t}^{d}\right)$ decreased from 4.7 to $3.5-4.5 \%$.

Originality. Comparative quality indicators of the resulting raw material (ordinary brown coal, carbon clay and their mixtures) and solid combustible fuel after its modification in the thermal vacuum installation and separation were obtained. It is predicted that it is possible to obtain an analogue of coal grades D, DG, and G from dried heat-treated brown coal with partial removal of mineral impurities and sulfur. The combination of processes of vacuum drying, heat treatment with the use of special methods of separation became the basis for the development of technological regulations for the processing of brown coal to produce fuels with high energy characteristics.

Practical value. The effective scheme and conditions of the open mining works in the development of a typical coal deep deposit in order to increase its energy characteristics are substantiated. Technological solutions for processing of brown coal have been developed to enhance its energy characteristics, which includes the following processes: preparation of coal (preparation of raw coal and carbon clay; drying of coal mass; conditioning of coal mass); heat treatment of carbon mass and its conditioning; magnetic and electrostatic separation; agglomeration of the concentrate. The implementation of a fundamentally new approach to the development of deposits and the subsequent processing of brown coal first of all will lead to restoration of non-operating coalmining enterprises in Ukraine, reducing the man-made load on the environment, providing new jobs for people.

Keywords: brown coal, open deposit development, processing, crushing, thermal and vacuum drying, heat treatment, separation, fuel base, energy independence

Introduction. Due to the transfer of anthracite-fired boilers of electricity production plants (EPP) and heat and electricity production plants (HEPP) to the gas group of coal, the production of this type of fuel in Ukraine is not sufficient to cover the country's energy balance. Therefore, to cover the deficit, Ukraine buys coal in large volumes abroad.

At the same time, Ukraine possesses significant reserves of brown coal. However, the characteristics of this type of fuel are not suitable for use on existing EPPs and HEPPs. In this regard, the development of technological solutions for the brown coal processing will allow expanding the fuel base of heat energy facilities, as well as affecting the energy balance of the country as a whole. Moreover, by removing of significant amount of sulfur from recycled brown coal, the environmental burden in an urban area will be reduced [1].

The involvement of carbon clays in the extraction and processing operations not only broadens the base of this technology application, but also increases the mining efficiency enterprises, and, also reduces the environmental burden during open mining, which is not less important $[2,3]$.

(C) Babets Ye.K., Bielov O.P., Shustov O.O., Barna T.V., Adamchuk A.A., 2019
Literature review. The studies conducted in recent years on the open mining technology suggest that the disclosure [4], preparation for operation, as well as the development of deep horizons of quarries of coal deposits is relevant $[5,6]$.

Among all significant research results, the following should be highlighted: the analysis of the current operation state of brown coal mining enterprises in order to establish cost-effective technologies for its processing [7]; estimation of investment attractiveness of ammonia production with application of financial and mathematical cost methodology and development of recommendations for coal mining and processing to create an entire processing enterprise $[8,9]$.

The scientists of the NTU "Dnipro University of Technology", in turn, provided historical data [10], analyzed the current state, gave experience and prospects for the complex application and processing of brown coal [11, 12].

The previous studies on thermal effects on coal at low temperatures for the removal of capillary and surface moisture (drying), as well as at higher temperatures, for semi-coking and coking processes in the range from 200 to $800{ }^{\circ} \mathrm{C}$ were aimed mainly to execute the following [13]:

1. Ensuring minimal energy consumption for drying brown coal. 
2. Determination of quantitative and qualitative characteristics of gaseous and liquid semi-coking products, including solid residue. Gaseous and liquid semi-coking products were considered mainly as raw materials for further chemical technology, and the solid residue was studied for internal surface and sorption properties, as well as for use in metallurgical processes [14].

In the course of the drying performed in a vacuum drier, it was found that there were changes at the molecular level in the brown coal. Thus, the composition study on sulfur and nitrogen heteroatoms showed their lower content in dry coal. Despite the fact that the coal is subjected to a small thermal effect, it is assumed that due to the high-intensity steam forming in pores of a coal particle a partial destruction of organic matter (destruction) occurs and, therefore, the least strong chemical bonds along the carbon-heteroatom line break.

The obtained final humidity values of up to $1 \%$ indicate that not only the surface and capillary moisture, but also the adsorption and possibly chemical bonded moisture is evaporated during thermal vacuum exposure to the brown coal. The granulometric composition of the dried brown coal was less than $1 \mathrm{~mm}$ in size. The studies of the brown coal thermal vacuum drying process will allow determining more precisely not only the energy characteristics of the method, but also the influence on the molecular structure of the coal substance [15].

The previous works and studies on semi-coking processes have focused primarily on enhancing the yield and study of gaseous and liquid products. The solid residue was almost not considered as a product for energy purposes. Due to the fact that heteroatom elements are the most important elements for determining the energy value of solid minerals, and at 150$200{ }^{\circ} \mathrm{C}$ thermal destruction of brown coal and the release of volatile substances in the form of $\mathrm{CO}_{2}, \mathrm{CO}$, nitrogen and sulfur compounds begins, which affects the reduction of the content of heteroatoms in the coal substance. This suggests that the coal energy features are increasing significantly, and such indicators as the yield of volatile substances and sulfur are reduced.

Thus, during the thermal treatment there are changes in the structural and chemical parameters of coal. However, at the same time, there is a simultaneous increase in the relative portion of inorganic substances (ash). Therefore, the question of its reducing or removal becomes relevant. The literature mainly focuses on the study on chemical composition of semi-coking products; however there is almost no description of the results of research on enrichment the brown coal semi-coke. It is known that brown coal is practically not enriched by gravity and flotation methods. However, in the scientific literature there are studies on the possibility of extracting of inorganic substances from low-grade metamorphism coal, including brown coal [16, 17].

Thus, technological solutions for the extraction and processing of brown coal and giving it the properties of gas group coal, solves the problems of energy security of the country and reduction of import of hydrocarbons.

Unsolved aspects of the problem. Brown coal, being a lower grade (carbonation level) solid fuel, differs significantly in its properties from black group coal that are widely used in the country's energy sector. High levels of humidity, output of volatile, sulfur and often ash content hinder the involvement of brown coal in the energy balance of Ukraine.

The development of environmentally friendly and energy efficient technological solutions for processing of brown coal (drying and mineral removal, sulfur content reduction) with simultaneous artificial aging (carbonation) will allow it to find a wide application, potentially reducing the country's dependence on import hydrocarbon.

Purpose. Substantiation and development of technological solutions for the open development and processing of brown coal to improve its quality characteristics and application at energy production enterprises.

Results. Explored coal reserves in Ukraine amount to 56.5 billion tons, 5-15 billion tons of which is suitable for nonfuel processing. State energy supply and long-term production of a wide range of chemical products are mainly related to this type of resources. Most reserves are represented by low-metamorphosed black and brown coal, which, although beds not deeply, has high sulfur and ash content. The given qualitative indicators of coal complicate its energy application, but do not interfere its chemical processing in modern energy-technological processes.

It is projected that with the simultaneous commissioning of coal mining enterprises, Ukraine can produce at least 15 million tons of brown coal annually, and taking into account carbon clays, it can produce much more than 20 million tons/year. Calculating for 1 per ton of conditional fuel, the coal production can amount to more than 4.7 million tons, which will fully cover the projected shortfall of gas group coal in the amount of 4.4 million tons/year by 2030 . However, brown coal by its consumer characteristics significantly differs from gas coal, and especially from anthracite.

To perform the studies on improving the quality characteristics of brown coal, the ratios of components and elements of typical brown coal and carbon clays, as well as indicators of their technical analysis and elemental composition are provided (Fig. 1, Table 1).

Development of a feasible technological scheme of open mining operations and establishment of indicators of the coal quarry productivity. The first stage of research on the development of technological solutions for processing of brown coal to improve its energy features is to establish the performance (production capacity) indicators of a brown coal quarry with the simultaneous extraction of carbon clays as associated minerals. Brown coal lies close to the surface, which stipulates its mining in the most cost-effective way - opencast mining (at quarries). It is advisable to consider increasing the productivity of the quarry (open mine) for mining coal mass on the basis of the powerful Novo-Dmytrivske coal deposit (North-Western Donbas), which contains minerals of appropriate quality for further processing.

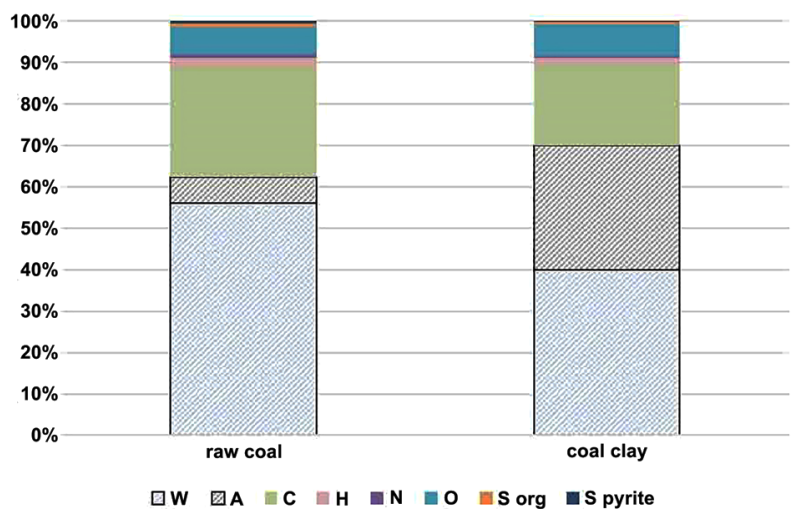

Fig. 1. The diagram of ratios of components and element of typical brown coal and carbon clays

Table 1

Characteristics of carbon clays $(\mathrm{CC})$ and brown coal (BC)

\begin{tabular}{|l|c|c|c|c|c|c|}
\hline \multirow{2}{*}{\multicolumn{1}{c|}{ Deposit }} & \multicolumn{3}{|c|}{$\begin{array}{c}\text { Technical } \\
\text { analysis, \% }\end{array}$} & \multicolumn{3}{c|}{$\begin{array}{c}\text { Element } \\
\text { composition, \% daf }\end{array}$} \\
\cline { 2 - 8 } & $W^{a}$ & $A^{d}$ & $\left(S_{t}^{d}\right)$ & $\mathrm{C}$ & $\mathrm{H}$ & $\mathrm{O}+\mathrm{N}+\mathrm{S}$ \\
\hline CC, Bandurivske & 6.7 & 59.4 & 2.6 & 51.4 & 6.1 & 42.5 \\
\hline BC, Bandurivske & 13.1 & 16.4 & 3.2 & 63.5 & 5.8 & 30.7 \\
\hline CC, Verbolozivske & 8.2 & 51.1 & 2.9 & 51.5 & 5.3 & 43.2 \\
\hline BC, Verbolozivske & 12.3 & 18.4 & 2.7 & 62.4 & 5.1 & 32.5 \\
\hline CC, Morozivske & 7.1 & 57.5 & 0.6 & 64.1 & 5.9 & 30.0 \\
\hline CC, Kostiantynivske & 2.6 & 78.2 & 1.5 & 65.8 & 5.8 & 28.4 \\
\hline
\end{tabular}


Preliminary analysis of the design indicators and operational experience of more than 300 domestic and foreign open miners, which develop slope and steeply descending deposits in a depth of $200 \mathrm{~m}$ or more, shows that their rock mass productivity is connected with the contours of a quarry field. Depending on their form, the considered quarries are joined into groups: having a small $\left(L_{q}=0.3-1.9 \mathrm{~km}\right)$, an average $\left(L_{q}=\right.$ $=2.0-4.2 \mathrm{~km})$ and a large $\left(L_{q}=4.6-11 \mathrm{~km}\right)$ length, as well as narrow $\left(L_{q} / \mathrm{B}_{q}=2.01-14.4\right)$ and rounded $\left(L_{q} / \mathrm{B}_{q}=1.0-2.0\right)$ [18].

According to the classification of quarries [19], it was found that mainly synclinal deposits like Novo-Dmytrivske or steeply descending powerful deposits are developed by rounded quarries. Based on the correlation analysis of the parameters of the rounded coal powerful quarries, their rock mass productivity is subject to the following regularity

$$
\begin{gathered}
A_{r \cdot m}=9.24 L_{q}+44 B_{q}+0.093 H_{q}-102 ; \\
R=0.904 ; \quad \mu=21.5,
\end{gathered}
$$

where $L_{q}$ and $B_{q}$ are the length and width of a quarry field measured by the ground surface, $\mathrm{km} ; H_{q}$ is limiting mining depth, $\mathrm{m}$.

The large values of the correlation ratio $R$, as well as its reliability $\mu$, indicate a high correlation between the parameters of length $L_{k}$, width $B_{k}$ and limiting depth $H_{k}$ of the quarries under consideration. This allows drawing up conclusions about the objectivity, validity and system-accuracy of the obtained dependencies [18].

The annual quarry productivity by the mineral $A_{y}$ (million tons) can be set by this formula [20]

$$
A_{y}=\frac{A_{r \cdot m}}{1+K_{s}}
$$

where $K_{s}$ is the average overburden ratio, $\mathrm{m}^{3} /$ t.

According to the established geometric dimensions of the Novo-Dmytrivske coal quarry, its annual rock mass productivity makes $A_{r m}=9.24 \cdot 5.25+44 \cdot 2.5+0.093 \cdot 375-102=$ $=91.4$ million tons or 45.7 million $\mathrm{m}^{3}$.

Annual coal productivity $A_{y}$ with $K_{s}=3.96 \mathrm{~m}^{3} / \mathrm{t}$ is equal to 9 million tons. The obtained indicators are compatible with the standard during exploitation of the similar fields [18].

Thus, the productivity of the Novo-Dmytrivkyi quarry for extraction of brown coal in the first stage is assumed to be equal to 9-10 million tons or $4.5-5$ million $\mathrm{m}^{3}$ per year. The corrections of annual rock mass productivity of a quarry can be made according to the type of mining equipment and its productivity, the speed of deepening mining operations and the speed of their front movement, and are specified in accordance with the geological conditions of the deposit and the needs of the economy in commodity production. Annual volumes of coal mining and overburden rocks are calculated when substantiating the feasible mode of mining operations in terms of intensity of construction of the enterprise infrastructure, quality of coal processing, placement of associated minerals and production wastes in specialized storage facilities.

The mode of mining operations in conditions of the NovoDmytrivske coal deposit at the initial stage of development and during the construction of a quarry is growing. Taking into account the formation of the working boards of the quarry at an angle of about $15^{\circ}$, the average inclination angle of working ledges is $30-32^{\circ}$. Vertical average capacity of the Main, Composing and Top layers in sum makes about $m=69 \mathrm{~m}$. The width of the working platform varies from 89 to $135 \mathrm{~m}$. The working horizon with the thickness of $45 \mathrm{~m}$ is divided into two sub-ledges: upper with the thickness of $15 \mathrm{~m}$ and lower $-30 \mathrm{~m}$.

Based on the experience of the overburden works [7], the quarry field can be opened with the use of high-performance rotor-conveyor complexes. The overburden works are planned to be carried out with the use of the powerful rotary excavator SRs-6300 with a theoretical capacity of $14000 \mathrm{~m}^{3} /$ year and the

loading of the rock on a belt conveyor in a composition with an interstitial re-loading machine and dumping machine.

It is advisable to perform mining works with one-bucket straight mechanical shovel with a bucket capacity of at least $12 \mathrm{~m}^{3}$ in combination with dump trucks. The composition of such complex corresponds to the increased strength of brown coal in the array.

Two variants of deposit development with longitudinal and transverse movement of the field of operations are considered in the paper. The options for opening the deposit and the order of its exploration within the boundaries of a future quarry include: the option $I-$ the direction of the mining works front from the southeast to the northwest and the option $I I-$ the construction of an open mine with the direction of the mining works front from the southwest to the northeast (Fig. 2).

Fig. 2 shows perspective quarry boundaries that are set for production of brown coal of the Composing horizon in the wings of the syncline, their development will be carried out at the last stage of mining of deposit. Considering the above options of the deposit development, the most cost-effective option is the option $I I$.

When planning the productivity of the Novo-Dmytrivske open mine by the mineral, the annual movement of the mining works front and the period of the deposit development by the quarry were obtained, the calculation data are submitted in Table. 2.

The deposit development period is calculated with the following formula, years

$$
T=\frac{V_{M R}}{M_{m} \cdot m \cdot L_{f}},
$$

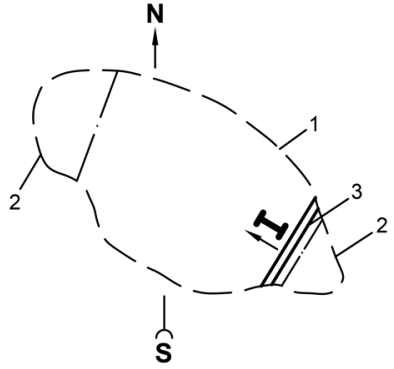

$a$

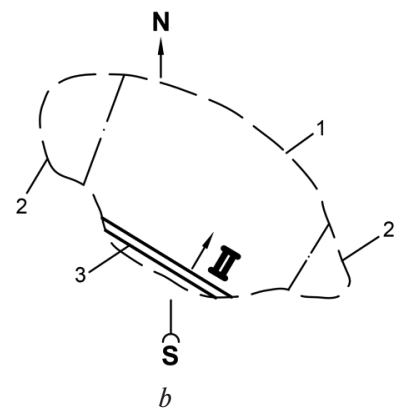

Fig. 2. The plan of development of a quarry field of the NovoDmytrivske brown coal deposit at transverse (a) and longitudinal (b) movement of mining works front:

1 - the border of the main site; 2 - perspective quarry boundaries; 3 - the direction of mining works front

Table 2

\begin{tabular}{|c|c|c|c|}
\hline 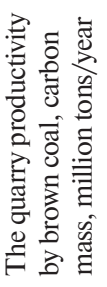 & 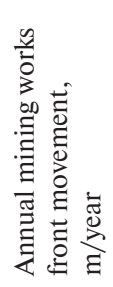 & 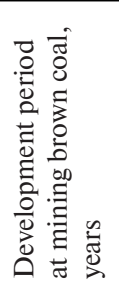 & 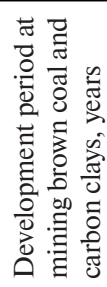 \\
\hline $1 / 2.2$ & 5.8 & 456 & 1190 \\
\hline $3 / 6.7$ & 17.4 & 152 & 397 \\
\hline $6 / 13.3$ & 34.8 & 76 & 198 \\
\hline $9 / 20$ & 52.2 & 51 & 132 \\
\hline
\end{tabular}

The indicators of increasing the productivity of the Novo-Dmytrivske open mine when mining brown coal and carbon clays 
where $V_{M R}$ is the volume of mineral within the deposit boundaries, $\mathrm{m}^{3}$.

Fig. 3 shows a chart of extraction of overburden rocks and brown coal together with carbon clays by years during the construction of the Novo-Dmytrivske open mine.

According to the above schedule, the most effective extraction of overburden rocks and mining of a mineral will be during the development by the option $I I$. The option $I$ will be more expensive, as it involves the extraction of large volumes of the overburden rocks which make over 14 million $\mathrm{m}^{3}$.

The studies have shown that carbon clays overlap the Upper and Composing coal horizons [7, 10]. Given their high ash content and low heat capacity, it is not possible to use all their volume as a separate accompanying raw material. However, in combination with an ordinary brown coal, the rock mass (ordinary brown coal + carbon clay) is an energy raw material that is suitable for further application.

The joint mining of ordinary brown coal and carbon clay can increase the amount of useful coal by more than 20 million tons per year. For comparison, the lower heat of combustion of the rock mass with the value of $1825.5 \mathrm{kcal} / \mathrm{kg}$ corresponds to the so-called energy-coal, which was previously burned at brown coal-fired heat and electricity production plants (HEPP) No. 1-3 in Oleksandriia city.

The heat of carbon clay combustion, by analogy with the Dniprovskyi Brown Coal Basin, calculated by combustible mass and by working fuel, respectively, make 4500-5600 and $700-900 \mathrm{kcal} / \mathrm{kg}$. The relevant ash content varies within 55-65\% (Table 3).

The following conclusions can be drawn from the substantiated parameters of brown coal mining. Implementation of the developed new technological solutions for the development of brown coal and carbon clay deposits and their further processing with their quality improvement will lead to:

1. Increase in the balance of mineral resources in deposits.

2 . Increasing of the mining enterprise productivity.

3. Opportunities for open-method development of those deposits, which previously were considered for none cost-effective mine extraction.

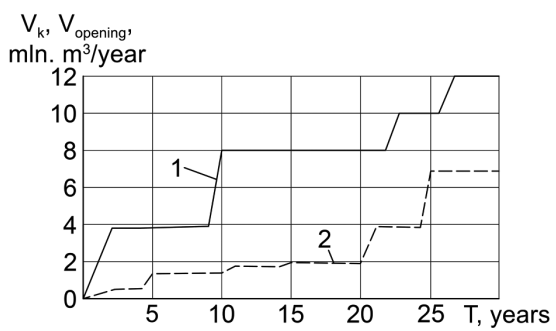

Fig. 3. The mode of mining during the opening of the deposit and construction of the open mine, taking into account mining of carbon clays:

1 - the overburden volume; 2 - the volumes of brown coal and carbon clays

Table 3

Estimated values of qualitative characteristics of carbon clay rock mass of the Novo-Dmytrivske open mine

\begin{tabular}{|l|c|c|c|c|}
\hline \multicolumn{1}{|c|}{ Indicator } & $\begin{array}{c}\text { Meas. } \\
\text { unit }\end{array}$ & $\begin{array}{c}\text { Work } \\
\text { mass }\end{array}$ & $\begin{array}{c}\text { Dry } \\
\text { mass }\end{array}$ & $\begin{array}{c}\text { Combustible } \\
\text { mass }\end{array}$ \\
\hline Moisture content & $\%$ & 46.1 & - & - \\
\hline Ash content & $\%$ & 21.5 & 40 & - \\
\hline Sulfur & $\%$ & 1.2 & 2 & 4 \\
\hline Output of volatiles & $\%$ & 20.0 & 37 & 62 \\
\hline Higher heat of combustion & $\mathrm{MJ} / \mathrm{kg}$ & - & - & 28.2 \\
\hline Lower heat of combustion & $\mathrm{kcal} / \mathrm{kg}$ & 1825.5 & - & - \\
\hline
\end{tabular}

4. Reducing the environmental burden.

5. Application of less expensive machinery during overburden works and reduction of capital costs.

6 . Reducing the mineral mining production costs.

7. Increasing the competitiveness of the country's fuel and energy sector.

The calculated values of the qualitative characteristics of the carbon mass are the basis for further processes of processing brown coal, namely: crushing, thermal vacuum drying, heat treatment and separation.

The description of technology scheme for processing brown coal. The technological process of obtaining fuel with increased energy characteristics from brown coal and carbon clays is represented by the principle technological line of apparatus and includes the following technological processes:

1. Coal preparation:

a) crushing of raw coal and carbon clay;

b) drying of carbon mass;

c) conditioning of dry carbon mass.

2. Heat treatment of carbon mass and its conditioning.

3. Separation of mineral and organic mass.

4. Lumping of organic mass.

Each technological process is provided with an appropriate design of apparatus, technological transport, steam, water and electricity supply systems, systems for ensuring safe running of the process, devices for control and automation of environment protection equipment, other necessary equipment, buildings, structures.

The grinding process is performed to ensure an optimal fractional composition of the coal for the next drying process. In the process of grinding, the surface of the coal particles increases and therefore heat transfers with less loses. Also, crushed coal is better fed inside a dryer, which has a positive effect on its productivity and energy consumption rates of a unit of evaporated moisture.

The crushing sequence is performed in the following order. Ordinary brown coal (fraction $0-300 \mathrm{~mm}$, moisture content of $58 \%$ ) is fed into the feeding hopper, where it is unloaded onto the hopper grate. Carbon clay (fraction $0-150 \mathrm{~mm}$, moisture of up to $46 \%$ ) is also fed into the feeding hopper. Coal and carbon clays are unloaded from the hopper through conveying system for pre-crushing in the hammer crusher, where the ordinary coal and carbon clay are mixed at the same time. After the hammer crusher, the rock mass is fed to a 2-roll crusher for pre-grinding to a size of $0-40 \mathrm{~mm}$, and afterwards is fed to the hit-refractive hammer crusher, which is heated, where the coal is grinded to a fraction of $0-6(10) \mathrm{mm}$.

Crushed coal is transferred to the screen. The undersize fraction product with a fraction of $0-3(4) \mathrm{mm}$ enters the mixing plant and is then reloaded into the drying compartment. The oversize fraction product of a fraction 3(4)-10 $\mathrm{mm}$ is fed to a vertical conveyor-elevator that returns coal to the beginning of the crushing cycle.

The next stage of coal preparation for the further processing is its drying, i.e. the extraction of ballast in the form of moisture. In our case, this is feeding it in a heat vacuum dryer.

Thermal vacuum drying is carried out in the apparatus which combines the thermal effect and significantly reduced atmospheric pressure. The combination of these two factors can significantly reduce the heat consumption rate and reduce the residence a time of being crushed brown coal in the dryer. Dry coal should contain a minimum amount of moisture for the further processing.

Thermal vacuum method for drying and grinding is based on the principle of combining a rapid process of evacuation and thermal heating, with direct contact of the material with the heated internal surface of the spiral type hollow heater, which provides an instant heating of the wet material particles to the required temperature. The contact of the carbon material with the heated wall of the heater causes heat transfer from its wall to the surface layer of the material, and the reduced 
pressure inside the heating element allows drying and grinding the wet material at a temperature substantially lower than a temperature in atmospheric pressure.

When drying brown coal, the following values were established:

Initial moisture

Final moisture

$56-58 \%$

Drying time

Temperature of heat element

$2-15 \%$

$15 \mathrm{sec}$.

$250{ }^{\circ} \mathrm{C}$

$67^{\circ} \mathrm{C}$

coal temperature

up to $0.1 \mathrm{~mm}$

$300 \mathrm{~mm} \mathrm{Hg}$ Art.
Maximum specific heat consumption per $1 \mathrm{~kg}$ of evaporated moisture is $2250 \mathrm{~kJ} / \mathrm{kg}$

The appearance of coal before and after drying is presented in Fig. 4.

The following process of coal thermal treatment is carried out in the following sequence. The indicators of the technical (moisture, ash content, total sulfur content, volatile matter) and elemental (carbon, hydrogen, sulfur, nitrogen and oxygen content) analyses as well as the chemical composition of its ash (content of higher oxides of aluminum, silicon, iron, magnesium, calcium, sodium, potassium, sulfur) are determined in the dried and averaged sample of brown coal.

To perform the works on heat treatment of dry brown coal at different process modes, the specialists of SE "UKhIN" (Kharkiv city) selected brown coal for installations.

A sample was selected for complex analysis according to the following parameters: technical $\left(W_{t}^{r}, A^{d}, S_{t}^{d}, V^{\text {daf }}\right)$ and elemental $\left(\mathrm{C}^{\mathrm{d}}, \mathrm{H}_{\mathrm{d}}, \mathrm{N}^{\mathrm{d}}, \mathrm{O}^{\mathrm{d}}\right)$. In addition, the higher and lower combustion heat was determined in accordance with DSTU ISO 1928: 2006 "Solid mineral fuels. Determination of the highest combustion heat by burning in a calorimetric bomb and calculating the lowest combustion heat".

The results obtained are presented in the Tables 4 and 5.

The results show a high value of ash - about $40 \%$, which indicates that this coal does not refer to the "mother" brown coal, but more to carbon clay. Also, the working moisture content of $9.4 \%$ should be noted.

To avoid deviations in the values of the elemental analysis results, the data is presented for the dry state of a fuel.

Heat treatment of brown coal is carried out in the laboratory furnace designed by the SE "UKhIN" with a capacity of $5 \mathrm{~kg}$.

The studies show that under the temperature of the initial sample, due to the conversion of the organic mass of the coal substance, the ash content increases.

This confirms that in the process of thermochemical conversions of brown coal at $350-400{ }^{\circ} \mathrm{C}$ there is a significant decrease in the content of functional oxygen-containing groups due to the cleavage of carboxyl and hydroxyl groups. Carbonyl groups are characterized by greater heat resistance, rather than functional ("unreactive") oxygen, which is a part of heterocycles, and other compounds, is stored in large quantities.

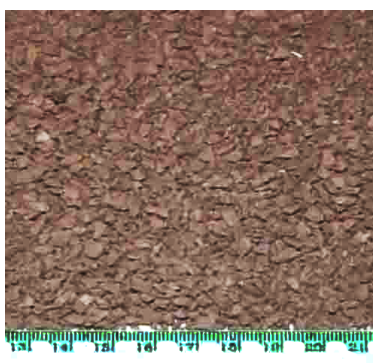

$a$

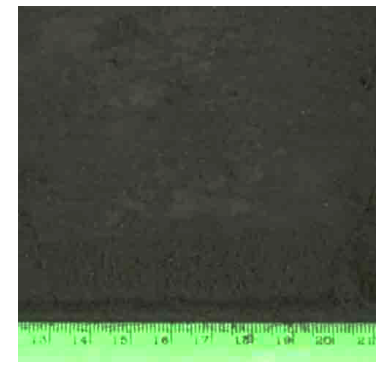

$b$
Fig. 4. Appearance pf brown coal particles before and after drying:

$a$ - before drying; $b$ - after drying
Table 4

Technological properties of dried brown coal

\begin{tabular}{|c|c|c|c|c|c|c|c|c|}
\hline \multirow{2}{*}{$\begin{array}{l}\stackrel{\Xi}{\Xi} \\
\text { Z }\end{array}$} & \multicolumn{5}{|c|}{ Technical analysis, \% } & 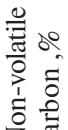 & \multicolumn{2}{|c|}{$\begin{array}{c}\text { Heat of } \\
\text { combustion, } \\
\mathrm{MJ} / \mathrm{kg}(\mathrm{kcal} / \mathrm{kg})\end{array}$} \\
\hline & $W_{t}^{r}$ & $W^{a}$ & $A^{d}$ & $S_{t}^{d}$ & $V^{d a f}$ & $F C^{d}$ & $Q_{s}^{d a f}$ & $Q_{i}^{r}$ \\
\hline $\begin{array}{l}\text { Brown } \\
\text { coal }\end{array}$ & 9.4 & 6.12 & 39.8 & 2.64 & 42.7 & 71.0 & $\frac{27.47}{6562}$ & $\frac{15.86}{3789}$ \\
\hline
\end{tabular}

Table 5

Elemental composition of the dried brown coal

\begin{tabular}{|c|c|c|c|c|c|}
\hline \multirow{2}{*}{ Name } & \multicolumn{5}{|c|}{ Elemental composition, \% } \\
\cline { 2 - 6 } & $C^{d}$ & $H^{d}$ & $N^{d}$ & $S_{t}^{d}$ & $O_{d}^{d}$ \\
\hline Brown coal & 40.49 & 3.82 & 0.45 & 2.64 & 12.8 \\
\hline
\end{tabular}

In fact, even after the brown coal has been heat treated at temperatures of 300(350), the indicators of treated brown coal become equivalent to the value of gas coal by such characteristics as the yield of volatiles, the content of elements, the higher heat of combustion.

However, due to the loss of a part of organic mass and an increase in the mineral component portion, this coal is not suitable for energy purposes and requires further operations for its processing.

After determining the yield of products of thermal treatment, the analysis for solid residue and resin content was carried out.

The qualitative characteristics of the solid residue are shown in Tables 6 and 7.

Analysis of the data provided in Tables 6, 7 show that increasing of the heat treatment temperature leads to an increase in the ash content in the solid residue, a decrease in the yield of volatiles, a carbon and hydrogen content in a dry substance.

Heat treatment of a mixture of brown coal and carbon clay allows not only reducing the yield of volatiles and increasing the calorific value on combustible mass, but also removing completely the surface moisture of material, which significantly changes the natural electrical conductivity of minerals and prevents particles from sticking.

Separation of heat-treated coal. The separation process considers different modes of operation and obtains fractions of semi-coke or heat-treated coal. The first fraction that contains the largest amount of organic part is the enriched coal itself. The second fraction with the maximum amount of ash is the "tail of enrichment".

The inorganic part of both fractions is studied for chemical composition (the content of higher oxides of silicon, aluminum, iron, magnesium, calcium, sodium, potassium and sulfur). The enriched coal fraction is studied for the content of carbon, hydrogen, sulfur, nitrogen and oxygen, ash content, moisture content and yield of volatile substances, calorific value.

A series of experiments carried out on different separators and at different operating modes gives an array of data from which the optimal mode of enrichment is chosen, taking into account the coal processing in the previous stages. After determining the optimal technological mode of enrichment, a pilot batch of high-calorie fuel is produced.

The starting material after the preliminary stages of crushing and mixing is fed into the hopper of initial feeding of enrichment plant. Through an adjustable shaking dispenser, the raw material is fed to a vibrating screen, which classifies it by size class $1 \mathrm{~mm}$. The high size ash content fraction $+1 \mathrm{~mm}$ enters the re-grinding and returns to the total flow, and the frac- 
Table 6

Technological properties of the solid residue in the process of heat treatment

\begin{tabular}{|c|c|c|c|c|c|c|c|c|}
\hline \multirow{2}{*}{ 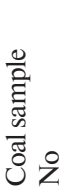 } & \multirow{2}{*}{ 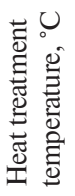 } & \multicolumn{5}{|c|}{ Technical analysis, $\%$} & \multicolumn{2}{|c|}{$\begin{array}{c}\text { Heat of } \\
\text { combustion, } \\
\mathrm{MJ} / \mathrm{kg} /(\mathrm{kcal} / \mathrm{kg})\end{array}$} \\
\hline & & $W^{a}$ & $A^{d}$ & $S_{t}^{d}$ & $V^{d}$ & $V^{\text {daf }}$ & $Q_{s}^{\text {daf }}$ & $Q_{i}^{r}$ \\
\hline 1 & 150 & 2.2 & 42.1 & 2.5 & 40.8 & 70.47 & 28.61 & 3801.7 \\
\hline 2 & 250 & 1 & 45.2 & 2.5 & 33 & 56.99 & 29.16 & 3670.1 \\
\hline 3 & 350 & 0.8 & 53.1 & 2.4 & 25.4 & 43.87 & 30.73 & 3316.1 \\
\hline 4 & 450 & 0.9 & 57.8 & 2.3 & 17.8 & 30.74 & 31.64 & 3076.2 \\
\hline 5 & 550 & 0.7 & 58.9 & 2.4 & 12.3 & 21.24 & 31.21 & 2953.5 \\
\hline 6 & 650 & 0.5 & 59.5 & 2.4 & 8.8 & 15.20 & 31.16 & 2905.9 \\
\hline
\end{tabular}

Table 7

Elemental composition of the solid residue in the process of heat treatment

\begin{tabular}{|c|c|c|c|c|c|c|}
\hline \multirow{2}{*}{$\begin{array}{c}\text { Coal } \\
\text { sample No }\end{array}$} & \multirow{2}{*}{$\begin{array}{c}\text { Heat treatment } \\
\text { temperature, }{ }^{\circ} \mathrm{C}\end{array}$} & \multicolumn{5}{|c|}{ Elemental composition, \% } \\
\cline { 3 - 7 } & $C^{d}$ & $H^{d}$ & $N^{d}$ & $S_{t}^{d}$ & $O_{d}^{d}$ \\
\hline 1 & 150 & 43.9 & 2.3 & 0.5 & 2.5 & 8.7 \\
\hline 2 & 250 & 42.6 & 2.0 & 0.5 & 2.5 & 7.2 \\
\hline 3 & 350 & 37.5 & 1.9 & 0.4 & 2.4 & 4.7 \\
\hline 4 & 450 & 34.3 & 1.8 & 0.4 & 2.3 & 3.4 \\
\hline 5 & 550 & 34.1 & 1.3 & 0.3 & 2.4 & 3.0 \\
\hline 6 & 650 & 34.0 & 1.1 & 0.3 & 2.4 & 2.7 \\
\hline
\end{tabular}

tion size $-1 \mathrm{~mm}$ size fraction immediately enters an electrical separator. Electrical enrichment is based on the use of differences of the electrical properties of the components of brown coal products. The wastes of the electric separator also go to the waste collector, the intermediate product and the concentrate of the separator are directed to the magnetic separator. Under the influence of magnetic field, the coal is separated into magnetic and non-magnetic products, depending on the magnetic properties of organic and mineral components. The magnetic product (wastes) is sent to the waste collector, and the non-magnetic product (concentrate) goes to the hopper for finished product and then goes to the lumping unit (Fig. 5).

The electrical method of separation lies in changing a motion trajectory of the charged mineral particles under the action of an electric field. There are many designs of electrical separators, which differ in the method of separation, methods of charging minerals, acting on particles of electrical and mechanical forces and other features. The electrical enrichment of brown coal is based on the use of differences in the electrical properties of coal petrographic varieties. Mineral (rock) particles in a sample have higher conductivity and ability to charge quickly while coal particles do not have these properties.

The developed experimental separator has a vibrator in the form of a vibrating tray, which is equipped with a heater for heating minerals prone to pyro-electrification up to $120-$ $200{ }^{\circ} \mathrm{C}$. Separation is made in an electric field up to $22 \mathrm{kV}$. An electric field is created between a metal grounded electrode (a precipitating drum) and a deflecting electrode to which a high voltage is applied. The voltage polarity is selected taking into account a sign charge that minerals receive when electrified.

The precipitating drum is made of stainless steel.

The technical characteristics of the experimental electric separator are shown in Table 8.

It was found that as the drum rotation speed increases, the separator performance increases, but the quality of the separated products is not ensured. In studies, the most favorable indicators of enrichment were obtained at a speed of the drum

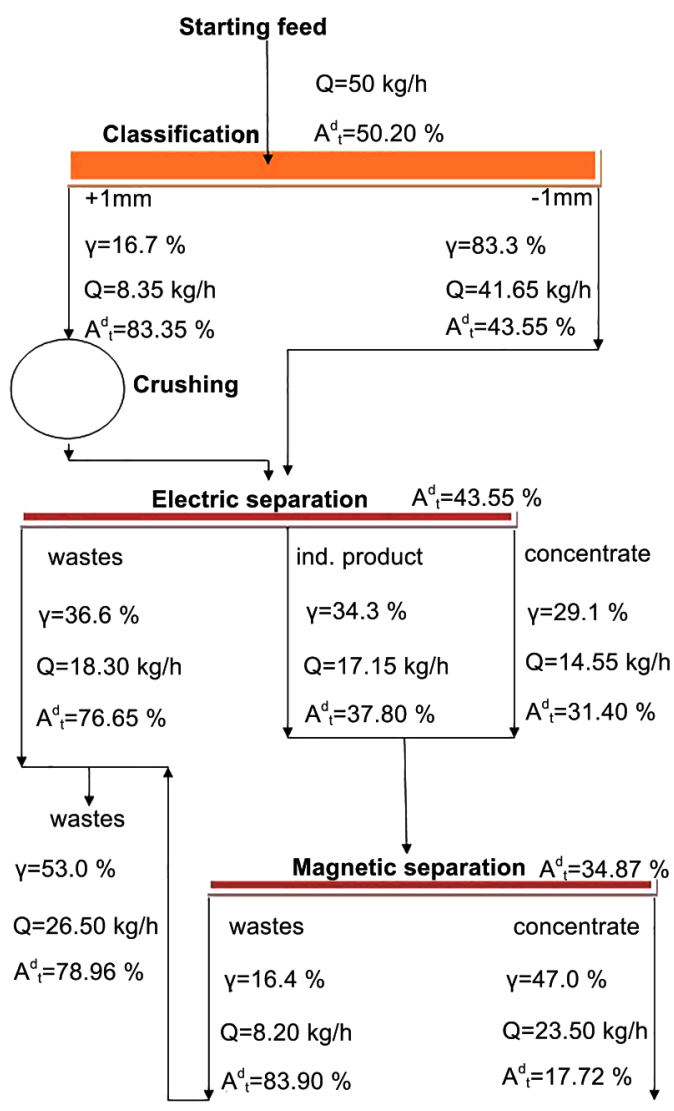

Fig. 5. Technology scheme of the brown coal enrichment

rotation around 50-65 rpm.

It was found in the study of the processes of electrical separation that in the previous stage there were obtained concentrates containing $37 \%$ of ash, and at the rotation of precipitating drum up to $65 \mathrm{rpm}$ and increasing the electric field strength up to $22 \mathrm{kV}$, the ash content of the electrical separator concentrates decreased by $6 \%$.

After the stage of electrical separation, the resulting concatenates were sent to magnetic separation for additional process.

Magnetic processes of coal enrichment are based on the use of differences in magnetic properties of the coal organic components and its mineral (rock) part.

Pure coal raw material is diamagnetic and its mineral components are represented by di-, para- and ferromagnetic minerals. It should be noted that the main component of the coal rock part is the clay substance. The impurities of free iron oxides are present in this substance, and often there are aluminum and iron hydroxides, siderite, sulfur pyrides, etc. The clay

Table 8

Technical characteristics of the experimental electric separator

\begin{tabular}{|l|c|}
\hline Productivity, $\mathrm{kg} /$ hour & 50 \\
\hline Maximal size of fed particles, $\mathrm{mm}$ & 3 \\
\hline Motor power, $\mathrm{kW}$ & 0.5 \\
\hline Power of electrical heaters, $\mathrm{kW}$ & 3.0 \\
\hline Electric field voltage, $\mathrm{kV}$ & $18-22$ \\
\hline Rated drum turn frequency, rpm. & $50-120$ \\
\hline Overall dimensions, mm, no more than & \\
\hline Length & 1870 \\
\hline Width & 1100 \\
\hline Height & 1530 \\
\hline Weight, $\mathrm{kg}$ & 320 \\
\hline
\end{tabular}


substance also contains groups of ferrous silicates with weak magnetic properties. Iron oxides and hydroxides are present in the clay substance in form of separate grains or films on clay minerals. The carrier of magnetic properties of the clay substance is apparently the iron oxides and hydroxides. Therefore, in the final stage of enrichment, we investigated the process of removal the ferro- and paramagnetic components of brown coal using magnetic separators.

The magnetic susceptibility of the particles to be extracted into the magnetic product is the main factor determining selection of the separator. Depending on the specific magnetic susceptibility of the minerals being extracted, the magnetic enrichment of coal is carried out in separators with a corresponding magnetic field.

The separation of particles of the enriched material by magnetic susceptibility is carried out in the separator working area, where the magnetic particles are tracked to the working body (drum, roll, disk), held on the working body and transported to the removal zone. The work area is the magnetic field of the separator efficiency and in the general case includes the area of extraction of magnetic particles and the zone of their transportation.

The rotation speed of the working body of the separators depends on the content of magnetic minerals in the initial feed, the required productivity and required quality of the separated.

In the course of research it was found that the most favorable for the brown coal enrichment is the roller magnetic separator. Its technical characteristics are given in Table 9.

A characteristic feature of roller separators is the presence of a closed electromagnetic system, which creates a field of high tension $(H=800-1600 \mathrm{kA} / \mathrm{m})$ in the gap near the jaws of a working body (a shaft, a roller or a disk).

The presence of an electromagnetic system allows setting the different modes of separation, which provides high technological performance.

It should also be noted that the brown coal enrichment sequence, performed first on an electric separator with the further final processing of obtained concentrates on the roller magnetic separator at a working body speed within $65-80 \mathrm{rpm}$ and induction of magnetic field within $0.35-0.5 \mathrm{Tl}$ made it possible to obtain a coal concentrate with an ash content of $17.7 \%$.

Based on the performed research studies, the comparative indicators of initial raw materials (ordinary brown coal and carbon clay) were obtained; mixtures of dry brown coal and dry carbon clay; indicators of the quality of carbon substance after heat treatment and enrichment were obtained (Figs. 6, 7).

Quality characteristics (Figs. 6, 7) depending on the genetic and technological characteristics of the coal, equipment settings and process line parameters can vary within $\pm 10 \%$.

Figs. 6, 7 show that the qualitative characteristics of solid fuels have the following values: the ash content of the mixture at the working state of the fuel (Ar) after heat treatment made $50.2 \%$, and after separation (concentrate) $-17.72 \%$; the lowest combustion heat $\left(Q_{t}^{r}\right)$, respectively, increased from 3316.1

Table 9

Technical characteristics of the roll magnetic separator for enrichment of brown coal

\begin{tabular}{|l|c|}
\hline Productivity, $\mathrm{kg} /$ hour & 50 \\
\hline Maximal size of fed particles, $\mathrm{mm}$ & 3 \\
\hline Motor power, $\mathrm{kW}$ & 0.5 \\
\hline Magnetic field induction, $\mathrm{Tl}$ & $0.2-1.0$ \\
\hline Roller turn rated frequency, rpm & $60-100$ \\
\hline Overall dimensions, mm, not more than & \\
\hline Length & 1240 \\
\hline Width & 810 \\
\hline Height & 1480 \\
\hline Weight, $\mathrm{kg}$ & 470 \\
\hline
\end{tabular}

to $5817.7 \mathrm{kcal} / \mathrm{kg}$. The yield of volatile substances decreased accordingly from 62 to $45 \%$.

The last processing stage may involve lumping (granulation) of the coal concentrate to produce the product in a form of briquettes or pellets/granules.

Thus, technological solutions for processing brown coal and giving it the properties of gas group black coal, resolves energy safety issues of the country and those of reducing imports of hydrocarbons. Involvement of carbon clays in the process of mining and processing not only extends the base of application of this technology, but also improves the efficiency of mining enterprises, and, what is also important, reduces the environmental burden during open-mining operations.

Conclusions.

1. The rational scheme of mining brown coal is suggested; the parameters of brown coal extraction with increasing the productivity of the open mine of the Novo-Dmytrivske deposit of up to 9 million tons per year, and with the involvement of, respectively, up to 20 million tons of carbon clays annually are established.

2. Technological solutions for the extraction and processing of brown coal have been developed to enhance its energy characteristics, including the following processes: preparation of coal (preparation of raw coal and carbon clays; drying of coal mass; conditioning of coal mass); heat treatment of carbon mass and its conditioning; magnetic and electrostatic separation; lumping of concentrate (finished products). Each technological process is supported by an appropriate equipment design, technological transport, steam, water and electricity supply systems, systems for ensuring safe process management, devices for control and automation of environmental

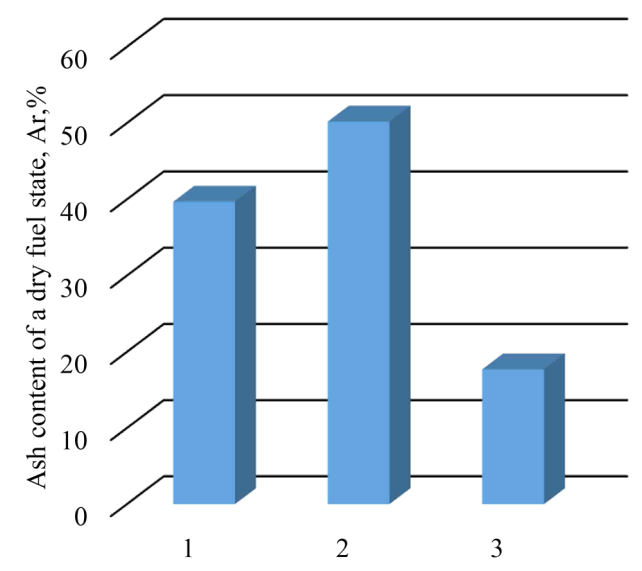

Fig. 6. Comparative diagram of ash content in samples:

1 - mixtures of dry brown coal and carbo clay; 2-mixtures after heat treatment; 3 - concentrate after separation

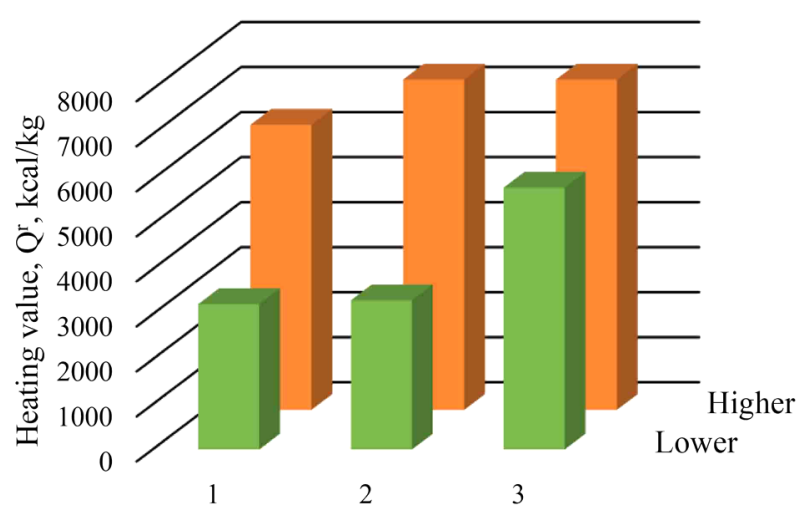

Fig. 7. Comparative diagram of combustion heat of samples:

1- mixtures of dry brown coal and carbon clay; 2- mixtures after heat treatment; 3 - concentrate after separation 
protection equipment, other necessary equipment, buildings, structures.

3. Drying of brown coal and carbon clay conducted in the pilot vacuum dryer shows the maximum extraction of moisture at acceptable rates of energy consumption. When the temperature of the heating element is $250{ }^{\circ} \mathrm{C}$ and the drying time is 15 seconds, the brown coal heating temperature does not exceed $76^{\circ} \mathrm{C}$.

4. Thermal treatment of dry brown coal with high ash content gives the opportunity to improve significantly the consumption indicators of a fuel while increasing the portion of the inorganic part. The high content of mineral part in the heat-treated coal requires its further treatment in electric separators.

5. The technological properties and elemental composition of the $\mathrm{BC}$ during its heat treatment are determined; in the temperature range from 150 to $600{ }^{\circ} \mathrm{C}$ the oxygen content decrease from about 21.1 to $12 \%$ from organic matter occurs, and the carbon content increases accordingly from 67 to $81.3 \%$.

6 . On the basis of the performed research studies the comparative characteristics of initial raw materials (ordinary brown coal and carbon clay) were obtained; mixtures of dry brown coal and dry carbon clay; quality indicators of carbon matter after heat treatment and enrichment were obtained. The following qualitative characteristics of solid fuels were established: the ash content of the mixture at the working state of a fuel $\left(A^{r}\right)$ after heat treatment was $50.2 \%$, and after separation (concentrate) $-17.72 \%$; the lowest combustion heat $\left(Q_{t}^{r}\right)$, respectively, increased from 3316.1 to $5817.7 \mathrm{kcal} / \mathrm{kg}$. The yield of volatile substances decreased from 62 to $45 \%$.

7. The implementation of a fundamentally new approach to the development and further processing of brown coal will, firstly, lead to restoration of non-operating coal mining enterprises in Ukraine, reduction of man-made environment effect, reduction of social tensions in regions by providing the population with new jobs, foundation of new enterprises and increasing of the regional domestic product, as well as revenues to all levels of budgets and social funds.

\section{References.}

1. Pavlychenko, A., \& Kovalenko, A. (2013). The investigation of rock dumps influence to the levels of heavy metals contamination of soil. Mining of Mineral Deposits, 237-238.

2. Sobko, B. Y., Denyschenko, O. V., Lozhnikov, O. V., \& Kardash, V.A. (2018). The belt conveyor effectiveness at the rock haulage under flooded pit excavations. Naukovyi Visnyk Natsionalnoho Hirnychoho Universytetu, (6), 26-32. https://doi. org/10.29202/nvngu/2018-6/4.

3. Anisimov, O., Symonenko, V., Cherniaiev, O., \& Shustov, O. (2018). Formation of safety conditions for development of deposits by open mining. E3S Web of Conferences, 60, 00016. https://doi.org/10.1051/e3sconf/20186000016.

4. Moldabayev, S., \& Aben, Ye. (2016). New technologii production mining on a steep board deep pits. International Journal of Applied Engineering Research, 21, 10458-10464.

5. Dryzhenko, A., Shustov, A., \& Moldabayev, S. (2017). Justification of parameters of building inclined trenches using belt conveyors. $7^{\text {th }}$ International Multidisciplinary Scientific GeoConference SGEM2017, Science and Technologies in Geology, Exploration and Mining. https://doi.org/10.5593/sgem2017/13/s03.060. 6. Blizniukov, V. H., \& Lutsenko, S. O. (2017). Improvement of technical criteria for comparative evaluation of mining operation options of iron ore open pits. Naukovyi Visnyk Natsionalnoho Hirnychoho Universytetu, (1), 44-49.

7. Shustov, O.O., Bielov, O.P., Perkova, T.I., \& Adamchuk, A.A. (2018). Substantiation of the ways to use lignite concerning the integrated development of lignite deposits of Ukraine. Naukovyi Visnyk Natsionalnoho Hirnychoho Universytetu, (3), 5-13. https://doi.org/10.29202/nvngu/2018-3/6. 8. Gumenik, I., \& Lozhnikov, O. (2015). Current condition of damaged lands by surface mining in Ukraine and its influence on environment. New developments in mining engineering /
Theoretical and practical solution of mineral resources mining, 139-145. https://doi.org/10.1201/b19901-26.

9. Rysbekov, K., Huayang, D., Kalybekov, T., Sandybekov, M., Idrissov, K., Zhakypbek, Y., \& Bakhmagambetova, G. (2019). Application features of the surface laser scanning technology when solving the main tasks of surveying support for reclamation. Mining of Mineral Deposits, 13(3), 40-48. https://doi.org/10.33271/mining13.03.040.

10. Belov, O., Shustov, O., Adamchuk, A., \& Hladun, O. (2018). Complex processing of brown coal in Ukraine: experience, practice, prospects. Solid State Phenomena, 277, 251268. https://doi.org/10.4028/www.scientific.net/ssp.277.251. 11. Petlovanyi, M., Kuzmenko, O., Lozynskyi, V., Popovych, V., Sai, K., \& Saik, P. (2019). Review of man-made mineral formations accumulation and prospects of their developing in mining industrial regions in Ukraine. Mining of Mineral Deposits, 13(1), 24-38. https://doi.org/10.33271/mining13.01.024. 12. Petlovanyi, M. V., \& Medianyk, V.Y. (2018). Assessment of coal mine waste dumps development priority. Naukovyi Visnyk Natsionalnoho Hirnychoho Universytetu, (4), 28-35. https://doi.org/10.29202/nvngu/2018-4/3.

13. Falshtynskyi, V., Dychkovskyi, R., Saik, P., \& Lozynskyi, V. (2014). Some aspects of technological processes control of an in-situ gasifier during coal seam gasification. Progressive Technologies of Coal, Coalbed Methane, and Ores Mining, 109-112. https://doi.org/10.1201/b17547-20.

14. Falshtynskyi, V.S., Dychkovskyi, R. O., Saik, P. B., Lozynskyi, V. H., \& Cáceres Cabana, E. (2017). Formation of thermal fields by the energy-chemical complex of coal gasification. $\mathrm{Nau}$ kovyi Visnyk Natsionalnoho Hirnychoho Universytetu, (5), 36-42. 15. Yi, L., Feng, J., \& Li, W. Y. (2019). Evaluation on a combined model for low-rank coal pyrolysis. Energy, 169, 10121021. https://doi.org/10.1016/j.energy.2018.12.103.

16. Bittner, J. D., Hrach, F. J., Gasiorowski, S. A., Canellopoulus, L.A., \& Guicherd, H. (2014). Triboelectric belt separator for beneficiation of fine minerals. Procedia Engineering, 83, 122-129. 17. Jiang, Y., Xie, Q., Zhang, Y., Geng, C., Yu, B., \& Chi, J. (2019). Preparation of magnetically separable mesoporous activated carbons from brown coal with $\mathrm{Fe}_{3} \mathrm{O}_{4}$. International Journal of Mining Science and Technology, 29(3), 513-519. https://doi.org/10.1016/j.ijmst.2019.01.002.

18. Anisimov, O. (2018). Research on parameters of the working area on an internal dump for developing open pits. Naukovyi Visnyk Natsionalnoho Hirnychoho Universytetu, (1), 2734. https://doi.org/10.29202/nvngu/2018-1/17.

19. Cherniaiev, O. V. (2017). Systematization of the hard rock non-metallic mineral deposits for improvement of their mining technologies. Naukovyi Visnyk Natsionalnoho Hirnychoho Universytetu, (5), 15-21.

20. Sergey, L. (2017). Open pits productivity control along with iron ore products demand variation. Quality-Access to Success, 18, 226-230.

\section{Розроблення технологічних рішень із видобутку й переробки бурого вугілля для підвищення його якісних характеристик}

\author{
Є. К. Бабець ${ }^{1}$, О. П. Бєлов ${ }^{2}$, О. О. Шустов ${ }^{2}$, \\ T. В. Барна ${ }^{2}$, А. А. Адамчук ${ }^{2}$
}

1 - Науково-дослідний гірничорудний інститут Державного вищого начального закладу „Криворізькій національний університет“, м. Кривий Ріг, Україна, e-mail: nigri@cabletv.dp.ua

2 - Національний технічний університет „Дніпровська політехніка“, м. Дніпро, Україна, e-mail: alexandriyaugol@ $\underline{\text { ukr.net }}$

Мета. Обгрунтування й розробка технологічних рішень із відкритої розробки родовищ і переробки бурого 
вугілля для підвищення його якісних характеристик і використання на енергогенеруючих підприємствах.

Методика. Для вирішення поставлених завдань використані наступні методи дослідження: аналітична оцінка ресурсів буровугільних покладів; геологічний та інженерно-гідротехнічний аналіз; системне й техніко-економічне обгрунтування показників видобувальних робіт i параметрів переробки вугілля; лабораторні випробування; натурний експеримент.

Результати. Запропонована раціональна технологічна схема відкритої розробки буровугільних родовищ України. Обгрунтовані планові параметри добування бурого вугілля 3 нарощуванням продуктивності буровугільного розрізу Ново-Дмитрівського родовища (за умови реалізації цього проекту) до 9 млн т. на рік, а із залученням у якості корисної копалини вуглистих глин - до 20 млн т. на рік відповідно. Розроблені технологічні рішення з термовакуумної та сепараційної модифікації бурого вугілля. Встановлені якісні характеристики отриманого концентрату для подальшого використання на енергогенеруючих підприємствах: зольність суміші на робочий стан палива $\left(A^{r}\right)$ після термічної обробки склала 50,2 \%, а після сепарації - 17,72 \%; нижча теплота згоряння $\left(Q_{t}^{r}\right)$ зросла з 3316,1 до 5817,7 ккал/кг; масова частка сірки $\left(S_{t}^{d}\right)$ знизилася з 4,7 до 3,5-4,5\%.

Наукова новизна. Отримані порівняльні показники якості вихідної сировини (рядового бурого вугілля, вуглистої глини та їх сумішей) і твердого горючого палива після його модифікації в термовакуумній установці й сепарації. Прогнозується, що з висушеного термообробленого бурого вугілля із частковим видаленням мінеральних домішок і сірки можливо отримати аналог вугілля марок Д, ДГ, Г. Поєднання процесів термовакуумного сушіння, термічної обробки з використанням спеціальних методів сепарації стало основою для розроблення технологічного регламенту переробки бурого вугілля для отримання палива з підвищеними енергетичними характеристиками.

Практична значимість. Обгрунтована ефективна схема й режим відкритих гірничих робіт при розробці типового родовища бурого вугілля глибокого залягання з метою підвищення його енергетичних характеристик. Розроблені технологічні рішення з переробки бурого вугілля для підвищення його енергетичних характеристик, що включає наступні процеси: приготування вугілля (підготовка сирого вугілля й вуглистої глини; сушка вуглистої маси; кондиціювання вуглистої маси); термічна обробка вуглистої маси й кондиціонування; магнітна та електростатична сепарація; кускування концентрату. Реалізація принципово нового підходу до розробки родовищ і наступної переробки бурого вугілля, у першу чергу, призведе до відновлення непрацюючих вугледобувних підприємств в Україні, зменшення техногенного навантаження на навколишнє середовище, забезпечення населення новими робочими місцями.

Ключові слова: буре вугілля, відкрита розробка родовищ, переробка, дроблення, термовакуумне сушіння, термічна обробка, сепарація, паливна база, енергонезалежність

\section{Разработка технологических решений по добыче и переработке бурого угля для повышения его качественных характеристик}

\author{
Е. К. Бабеи ${ }^{1}$, А. П. Белов ${ }^{2}$ А. А. Шустов ${ }^{2}$, Т. В. Барна ${ }^{2}$, \\ А. А. Адамчук ${ }^{2}$
}

1 - Научно-исследовательский горнорудный институт Государственного высшего учебного заведения „Криворожский национальный университет", г. Кривой Рог, Украина, e-mail: nigri@cabletv.dp.ua
2 - Национальный технический университет „Днепровская политехника“, г. Днепр, Украина, e-mail: alexandriyaugol@ukr.net

Цель. Обоснование и разработка технологических решений по открытой разработке месторождений и переработке бурого угля для повышения его качественных характеристик и использования на энергогенерирующих предприятиях.

Методика. Для решения поставленных задач использованы следующие методы исследования: аналитическая оценка ресурсов буроугольных залежей; геологический и инженерно-гидротехнический анализ; системное и технико-экономическое обоснование показателей добычных работ и параметров переработки угля; лабораторные испытания; натурный эксперимент.

Результаты. Предложена рациональная технологическая схема открытой разработки буроугольных месторождений Украины. Обоснованы плановые параметры добычи бурого угля с наращиванием производительности буроугольного разреза Ново-Дмитриевского месторождения (при условии реализации этого проекта) до 9 млн т. в год, а с привлечением в качестве полезного ископаемого углистых глин - до 20 млн т. в год соответственно. Разработаны технологические решения по термовакуумной и сепарационной модификации бурого угля. Установлены качественные характеристики полученного концентрата для дальнейшего использования на энергогенерирующих предприятиях: зольность смеси на рабочее состояние топлива $\left(A^{r}\right)$ после термической обработки составила 50,2 \%, а после сепарации - 17,72 \%; низшая теплота сгорания $\left(Q_{t}^{r}\right)$ возросла с 3316,1 до 5817,7 ккал/кг; массовая доля серы $\left(S_{t}^{d}\right)$ снизилась с 4,7 до 3,5-4,5\%.

Научная новизна. Получены сравнительные показатели качества исходного сырья (рядового бурого угля, углистой глины и их смесей) и твердого горючего топлива после его модификации в термовакуумной установке и сепарации. Прогнозируется, что из высушенного термообработанного бурого угля с частичным удалением минеральных примесей и серы можно получить аналог угля марок Д, ДГ, Г. Сочетание процессов термовакуумной сушки, термической обработки с использованием специальных методов сепарации стало основой для разработки технологического регламента переработки бурого угля для получения топлива с повышенными энергетическими характеристиками.

Практическая значимость. Обоснована эффективная схема и режим открытых горных работ при разработке типового месторождения бурого угля глубокого залегания с целью повышения его энергетических характеристик. Разработанные технологические решения по переработке бурого угля для повышения его энергетических характеристик включают следующие процессы: приготовление угля (подготовка сырого угля и углистой глины; сушка углистой массы; кондиционирование углистой массы); термическая обработка углистой массы и кондиционирование; магнитная и электростатическая сепарация; окускование концентрата. Реализация принципиально нового подхода к разработке месторождений и последующей переработки бурого угля, в первую очередь, приведет к восстановлению неработающих угледобывающих предприятий в Украине, уменьшению техногенной нагрузки на окружающую среду, обеспечению населения новыми рабочими местами.

Ключевые слова: бурый уголь, открытая разработка месторождений, переработка, дробление, термовакуумная сушка, термическая обработка, сепарация, топливная база, энергонезависимость

Recommended for publication by V.I. Pilov, Doctor of Technical Sciences. The manuscript was submitted 11.03.19. 